\title{
Petrography of Allanite-bearing Tonalite from Iwo Region, Osun State, Nigeria
}

\section{Petrografija tonalita z alanitom iz območja Iwo, Osun State, NIgerija}

\author{
Oziegbe E.J. ${ }^{1,}$, Ocan 0.0. ${ }^{2}$, Buraimoh A.O. ${ }^{1}$ \\ ${ }^{1}$ Department of Geosciences, Faculty of Science, University of Lagos, Nigeria \\ ${ }^{2}$ Department of Geological Science, College of Science, Engineering and Technology, Osun State University, Nigeria \\ * eoziegbe@unilag.edu.ng
}

\begin{abstract}
Primary, secondary and accessory minerals in tonalitic rocks from Iwo region of the Precambrian Basement Complex of Southwestern Nigeria were identified and analysed with the aim of determining the various processes involved during the crystallisation of magma. Thin sections of tonalite were prepared and studied with the aid of a petrographic microscope. The mineral assemblages observed are biotite, plagioclase, alkali-feldspar, amphiboles, pyroxene, quartz, muscovite and chlorite. Allanite, titanite, apatite and zircon occur as accessory minerals. Muscovite and chlorite are found to be secondary minerals. The mineral allanite has a characteristic form of zoning and shows evidence of metamictisation, and is surrounded by dark-coloured biotite having radioactive haloes. Titanite is anhedral to subhedral crystals and forms reaction rim round opaque minerals. Plagioclase shows evidence of compositional zoning as well as plastic deformation of the twin lamellae. The allanite observed is primary in nature and has undergone radioactive disintegration; chlorite and muscovite are formed by secondary processes of chloritization and sericitisation, respectively. The tonalite is formed as a result of rapid cooling of magma close to the Earth's surface.
\end{abstract}

Keywords: zoning, titanite, radioactive haloes, chloritization, sericitisation.

\section{Povzetek}

Z namenom določevanja različnih procesov, ki so vključeni pri kristalizaciji magme, so bili identificirani in opisani primarni, sekundarni in akcesorni minerali v tonalitnih kamninah iz pred-kambrijske podlage območja Iwo v jugozahodni Nigeriji. Zbruski tonalita so bili pripravljeni in raziskovani s pomočjo petrografskega mikroskopa. Opazovani minerali so: biotit, plagioklaz, alkalijski glinenec, amfibol, piroksen, kremen, muskovit in klorit. Alanit, titanit, apatit in cirkon se pojavljajo kot akcesorni minerali. Ugotovljeno je, da se muskovit in klorit pojavljata kot sekundarna minerala. Mineral alanit ima karakteristično obliko conarnosti in kaže prisotnost metamiktizacije ter je obkrožen s temno obarvanim biotitom z radioaktivnimi haloi. Titaniti so anhedralni do subhedralni kristali in tvorijo reakcijski obroč okrog neprozornih mineralov. Plagioklaz kaže prisotnost kompozicijske conarnosti in plastične deformacije dvojčičnih lamel. Alanit je naravno primaren in je prestal radioaktiven razpad, klorit in muskovit sta nastala kot sekundarna procesa kloritizacije in sericitizacije. Tonalit je nastal kot rezultat hitrega ohlajanja magme v bližini zemeljskega površja.

Ključne besede: conarnost, titanit, radioaktivni halo, kloritizacija, sericitizacija. 


\section{Introduction}

Iwo region, the area under study, is part of the Precambrian of Southwestern Nigeria, which is part of the Nigerian Basement Complex (Figure 1). Iwo region comprises of a migmatite-gneiss-granite complex and a metasupracrustal sequence (Figure 2). In addition to a widespread metasomatism that is a feature of this region, there is also the occurrence of early tonalitic and syenitic diapirs and late magmat- of varying compositions (granites, granodiorites, adamellite, quartz monzonites, syenites and pegmatites). In some cases, older granites have been reported to be foliated, defined by the alignment of the both feldspar crystals and mafic minerals [2]. Foliated older granites have been found in places such as Iwo, Idanre and Igarra in Southwestern Nigeria. However, it must be noted that older granites that have disordered arrangement of its feldspars are usually non-foliated. Rocks of Iwo area have

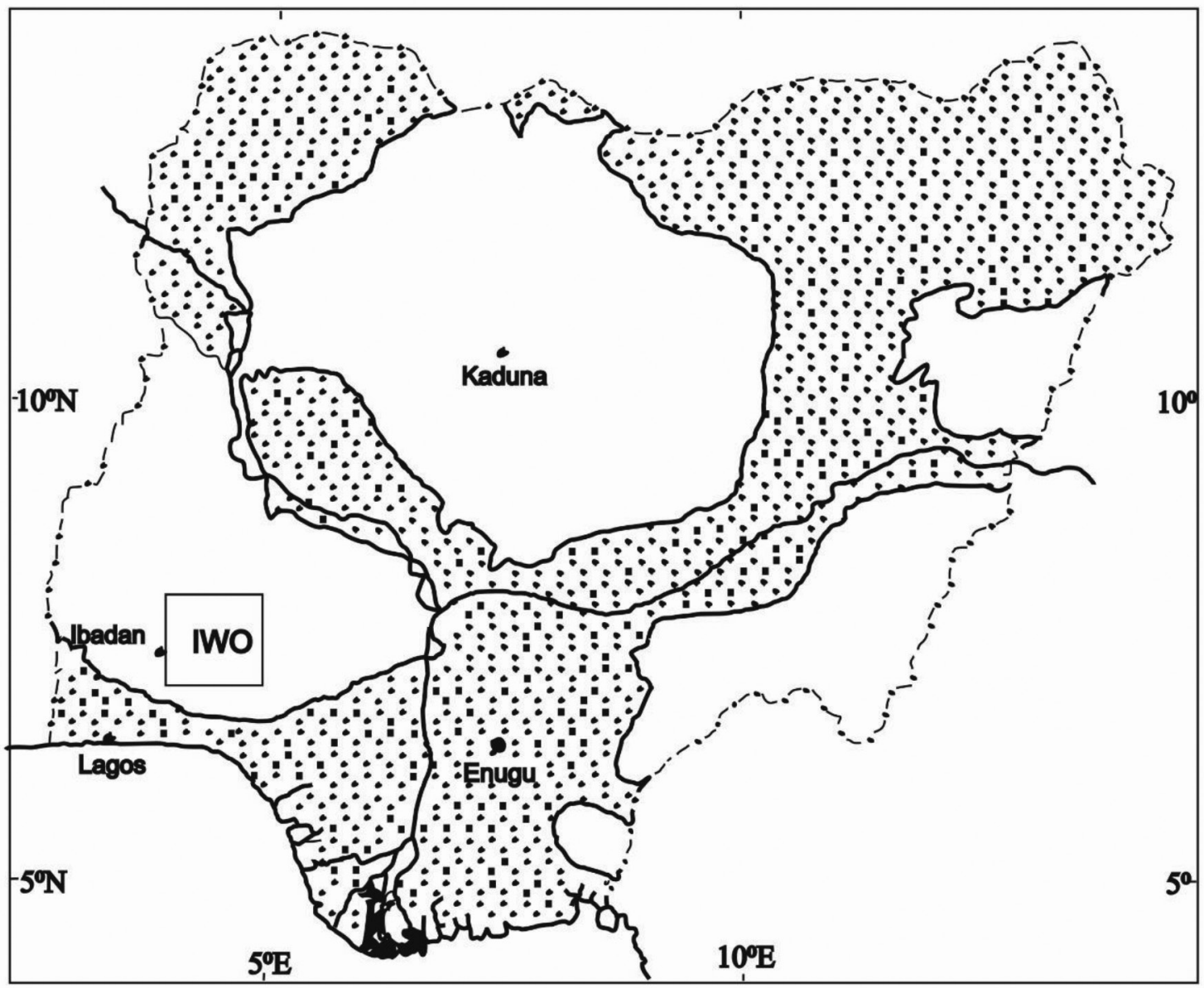

Figure 1: Map of Iwo region within Basement Complex of Nigeria. Stippled pattern indicates Cretaceous and younger sedimentary cover [1].

ic, granitic, pegmatitic, and aplitic intrusions in the large Iwo-Ikire complex [1]. Tonalite that is present in the study area belongs to the Older Granite Complex that comprises rocks with varying composition from the granodiorite to true granite [2]. This range comprises rocks been found to be affected by late reworking, metasomatism and granitic activity to varying extents [1]. Allanite (CaREE $\left(\mathrm{Al}, \mathrm{Fe}^{3+}\right) 2\left(\mathrm{Mg}, \mathrm{Fe}^{2+}\right)$ $\mathrm{Si}_{3} \mathrm{O}_{12}(\mathrm{OH})$ ) is a common accessory mineral in granitic and rhyolitic rocks. Allanite is a major residence site for LREE $[3,4]$. In some rocks, as 

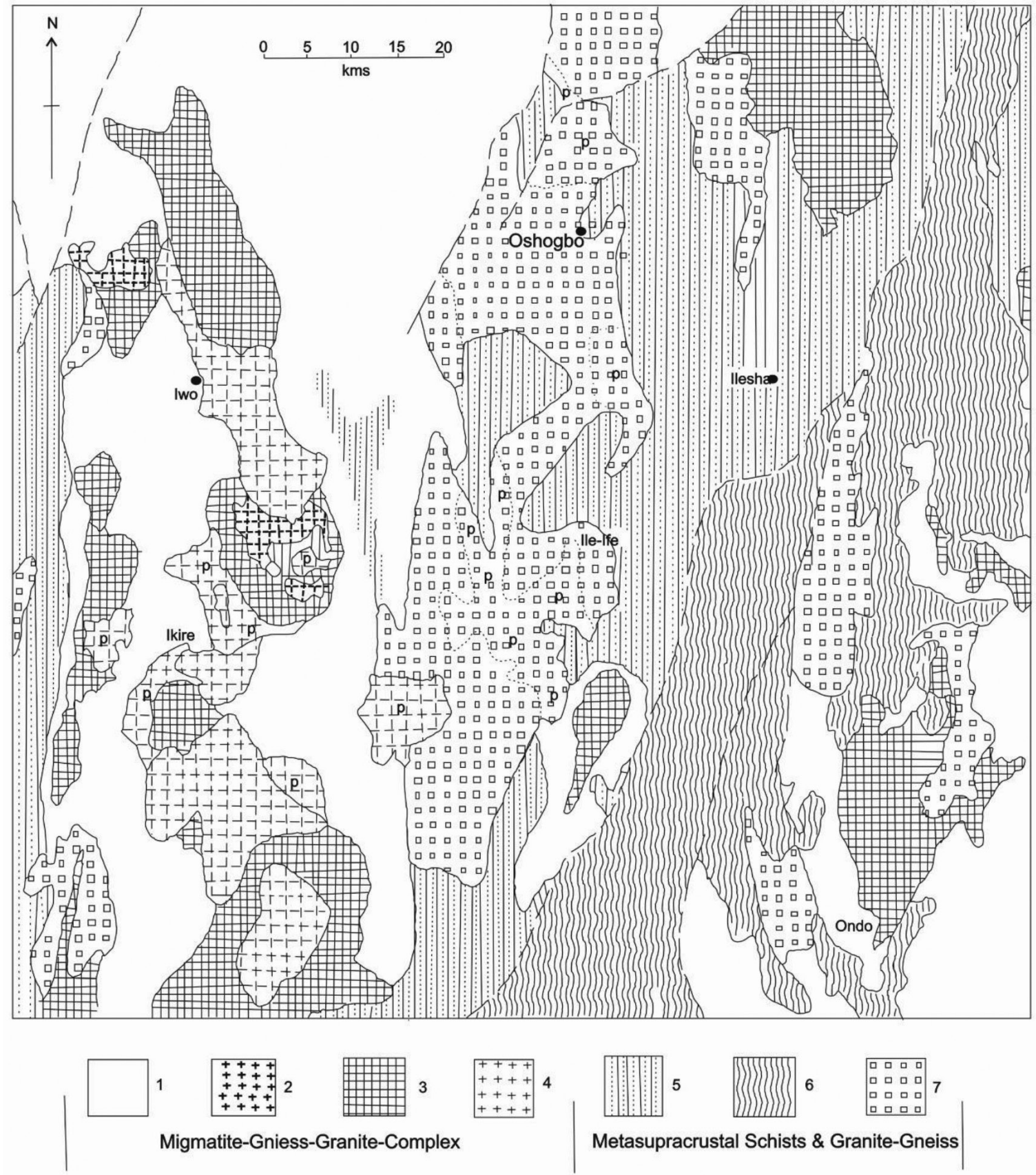

Figure 2: Geologic map of Iwo region modified after 1:250,000 sheet 60 (Iwo) of Geological Survey of Nigeria (GSN). 1, Migmatite-gneiss complex; 2, charnockite; 3, early granitic phases of Older Granite Cycle; 4, younger granitic phases of Older Granite Cycle; 5, amphibolite, amphibolite schist, and pelitic schist; 6 quartzite, quartz-schist, and quartzofeldspathic gneiss; 7, granitic-gneiss-dominated regions; p, pegmatite; $T$, tonalite. Thick broken lines indicate major faults [1].

high as $50-80 \%$ of Ce and La have been found in allanite. As a result of this, allanite has been used to track the behaviour of REE during melting, crystallisation and other igneous processes [5-7]. Titanite is found in different geological environments. Both allanite and titanite are common accessory minerals found in hydrothermal deposits $[8,9]$.

The tonalite under study is coarse-grained and foliated (Figures 3 and 4); foliation is marked by preferred orientation of long axes of tabular microcline grains and the long axes of the maf- 


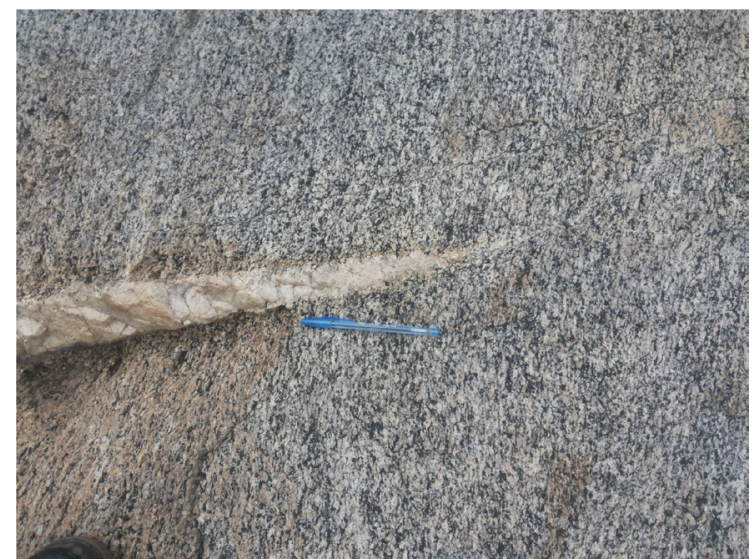

Figure 3: Field photograph showing tonalite. Take note of the vein quartz at the centre.

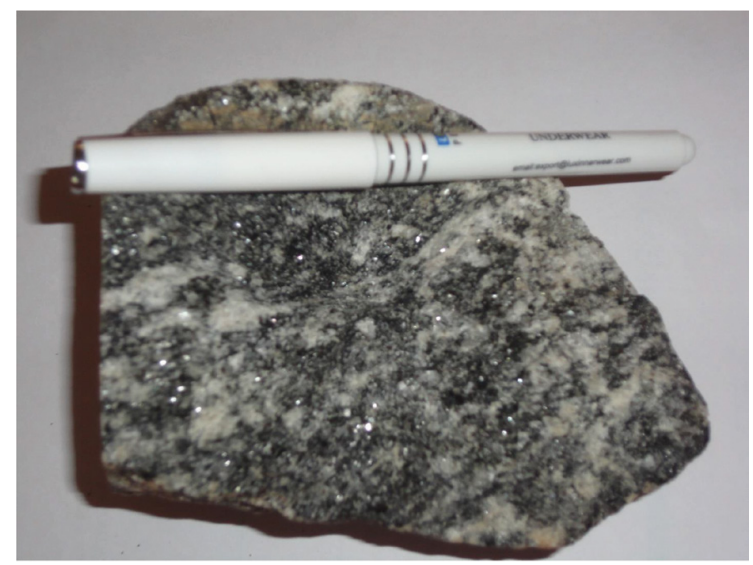

Figure 4: Hand specimen of tonalite from Iwo area.

ic minerals (biotite and pyroxene). The objective of this work is to petrographically describe the mineral assemblages with emphasis on the accessory minerals, allanite and titanite. Rock samples were taken from the following localities in Iwo region: Adana, Elemo, Elewonta and Isero/Ikonifin.

\section{Materials and Methods}

Four rock samples were taken from four different locations. Sixteen thin sections of these rocks were prepared at the laboratory of the Department of Geology, Obafemi Awolowo University. Detailed study of the thin sections were done using petrographic microscope at the Department of Geosciences, University of Lagos. Photomicrographs of areas of interest were tak- en both under plane polarised light (PPL) and cross polarised light (XPL).

\section{Results}

\section{Petrography}

The rock is porphyritic in texture, with phenocrysts of K-feldspar and plagioclase in matrix of biotite, amphibole and quartz. The main minerals are microcline, biotite, plagioclase, whereas green non-pleochloric pyroxene, amphibole (green hornblende) and quartz occur as minor minerals. Chlorite and muscovite occur as secondary minerals. Accessory minerals are allanite, zircon, titanite (sphene), apatite and opaque minerals. Allanite crystals are zoned, reddish brown in colour and strongly pleochroic with euhedral and subhedral crystals (Figures 5-7). Some crystals of allanite are altered whereas others are not; those that are altered have inclusions of opaque minerals mostly concentrated at the core (Figure 5c). Biotite is brownish in colour and subhedral in form, intergrown with allanite (Figure 5a).

Biotite consists of other minerals such as apatite (Figure 6a). Crystals of biotite show altered surfaces and display a form of preferred alignment. There is a close association between biotite and chlorite which is in turn surrounded by titanite (Figures $8 \mathrm{a}$ and $8 \mathrm{~b}$ ), all of which are in the proximity of microcline (Figure $8 b$ ). The plagioclase feldspar shows sign of (i) compositional zoning and (ii) deformation (Figures $8 \mathrm{c}$ and $8 \mathrm{~d}$ ). Plagioclase exhibits a combination of albite and Carlsbad twinning. Crystals of biotite occur as inclusions in plagioclase. A few crystals of titanite are euhedral, but majority are subhedral/anhedral. The subhedral grains occur as aggregates and are clustered around biotite, chlorite and opaque minerals. The anhedral form of titanite forms reaction rim around opaque minerals (Figures 9-11). Titanite is concentrated in and around biotite (Figures 8a, 9 and 10). There is a close association between titanite and biotite, amphiboles, plagioclase, chlorite and opaque minerals. In some samples, the titanite crystals that form reaction rim round opaque minerals are in contact with biotite, amphibole and plagioclase (Figures 10 and 11). 


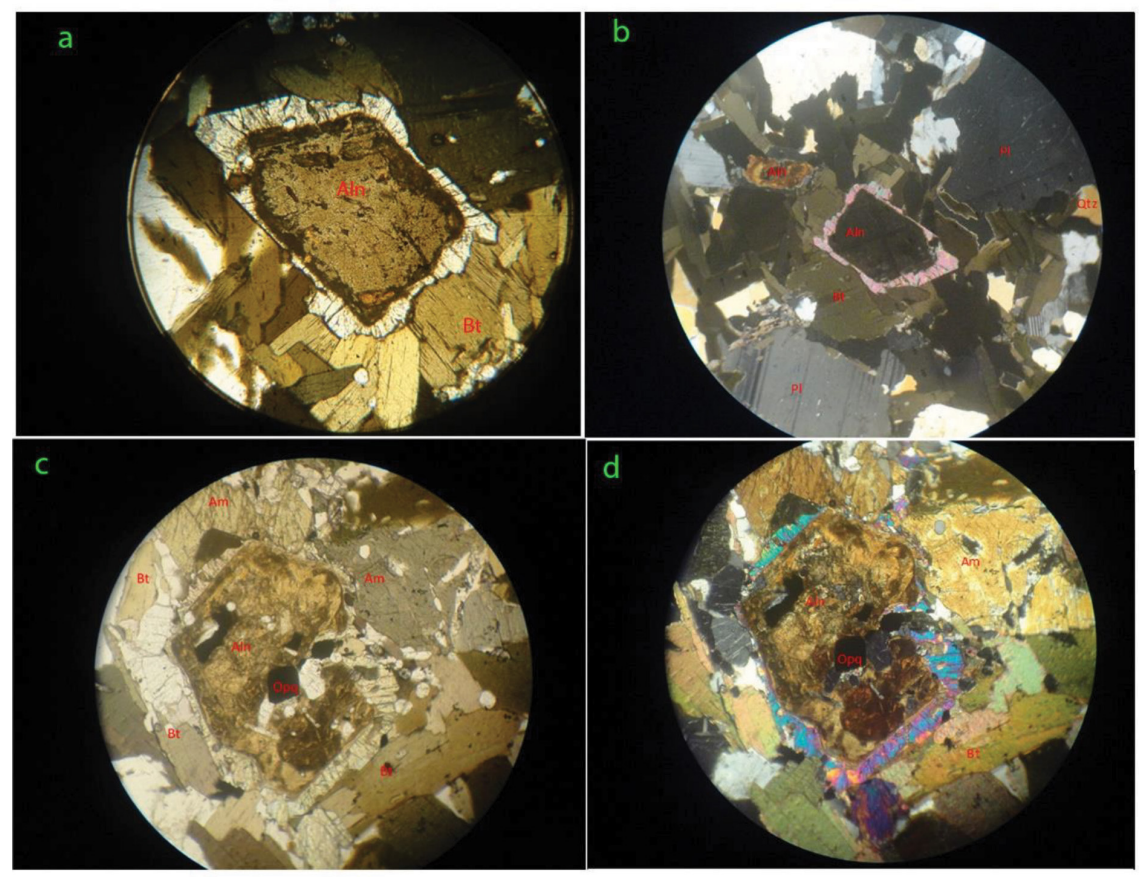

Figure 5: Photomicrographs showing: (a) zoned allanite (Aln) surrounded by biotite (Bt) crystals; biotite is darker at the edges closer to allanite than those away (PPL). (b) Zoned allanite (Aln), biotite (Bt), plagioclase (PI) and quartz (Qtz) (XPL). (c) Opaque $(\mathrm{Opq})$ minerals within a zoned allanite (Aln), take note of the close relationship between biotite and allanite (PPL). (d) Inclusions of opaque (Opq) minerals within a zoned allanite (Aln) (XPL).

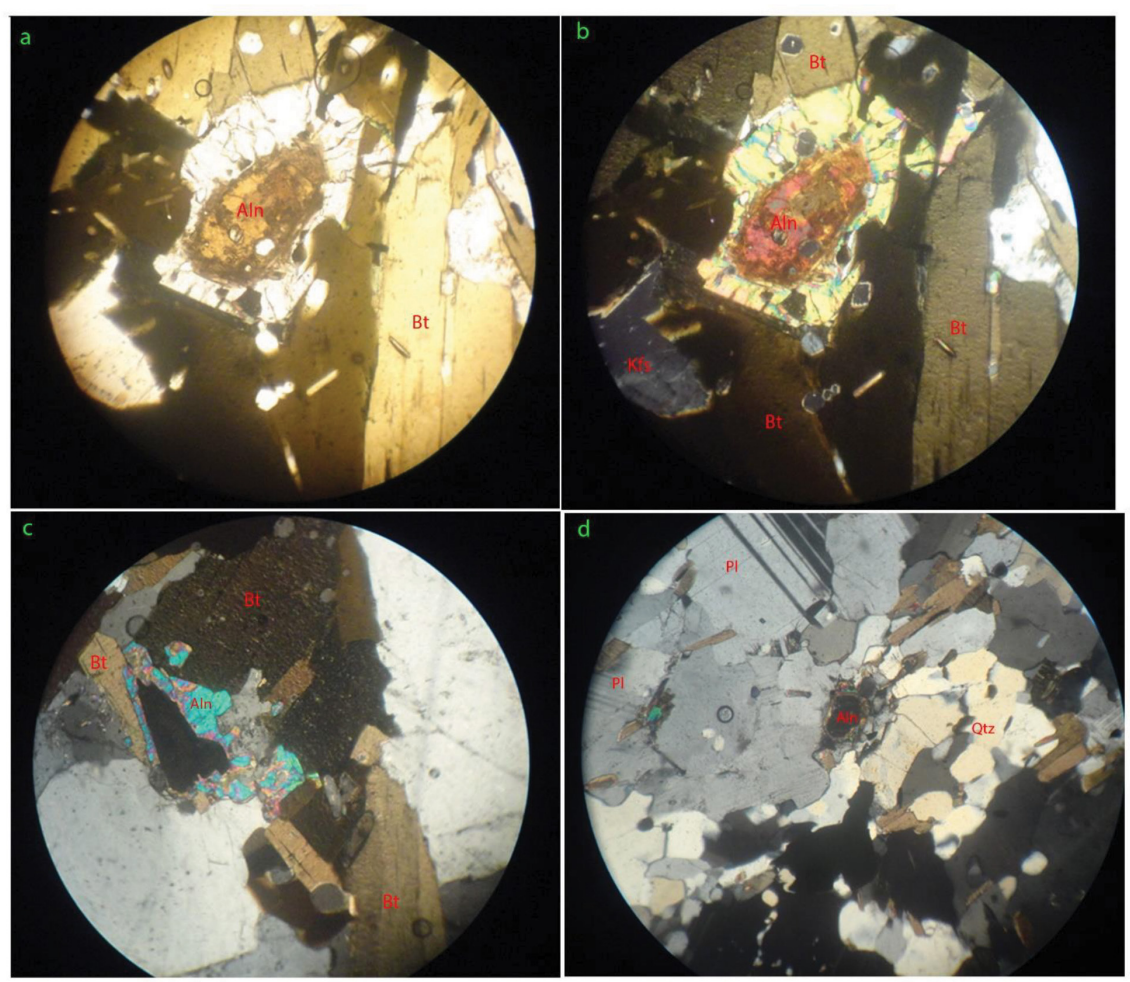

Figure 6: Photomicrographs showing: (a) numerous fractures within zoned allanite (Aln), there are inclusions of apatite in biotite (Bt) and the edges of biotite touching allanite are darker (PPL). (b) Opaque (Opq) minerals within allanite (Aln) (XPL). (c) Biotite (Bt) surrounding allanite (Aln), there are inclusions of allanite within biotite (XPL). (d) Close association between plagioclase (PI) and allanite (Aln) (XPL). 


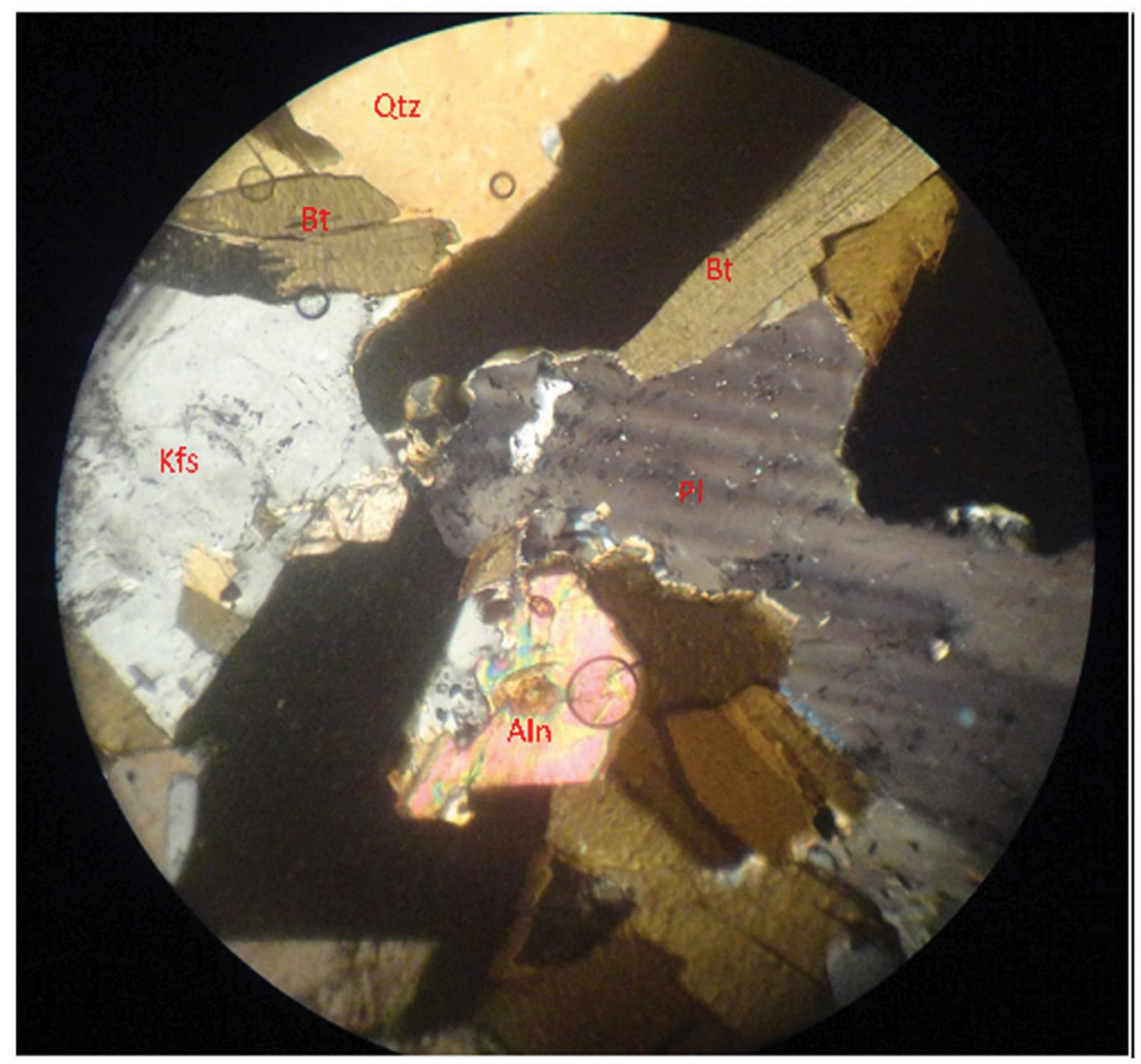

Figure 7: Photomicrograph showing sericitisation of plagioclase feldspars (PI) in close association with allanite (Aln) (XPL).

\section{Discussion}

The early formed minerals observed in the tonalite are allanite, amphiboles, plagioclase and quartz. The presence of allanite within biotite and hornblende can be attributed to early crystallisation. Amphibole (hornblende) is not present in all of the samples studied. Primary allanite has inclusions of ilmenite and is included in biotite as observed in the rock samples [10]. Primary allanite has been found in andesitic [11] and tonalitic [12] igneous rocks. Allanite is a high-Th-REE mineral of the epidote group and has been used in recent times in $\mathrm{Th}-\mathrm{U}-\mathrm{Pb}$ geochronology [9, 13-18].

The accessory mineral allanite is highly prone to alteration as a result of its metamict ability and there are inclusions of opaque minerals within the altered region of the crystals (Figure 5c). The biotite crystals surrounding allanite have radiation haloes that are darker at the contact edges closer to allanite (Figures $5 \mathrm{a}$ and 6a). This complex radioactive rim is an evidence of post-crystallisation process [19]. Allanite is one of the most common sources of primary uranium-bearing minerals [19]. In addition to the radioactive rim, there are numerous fractures on the altered allanite (Figure 6a) which can be attributed to the radioactive process. The degree of metamictisation of allanite depends on the degree of alpha-recoil damage [20]. This metamictisation coupled with hydrothermal alteration results in a variety of alteration products that tend to immobilise the REE and $\mathrm{Th}^{4+}$ in more stable secondary phases [21]. These formed phases has been found to be dependent on the physiochemical condition of the fluid which is present. Allanite and titanite have the potential of controlling REE in granitic magmas [5]. Titanite observed are of both primary and secondary types: the primary types are subhedral to eudedral in shape with some occurring as inclusions in biotite and amphiboles. The titanite-opaque mineral phase observed is an indication of the breaking down of titanite 

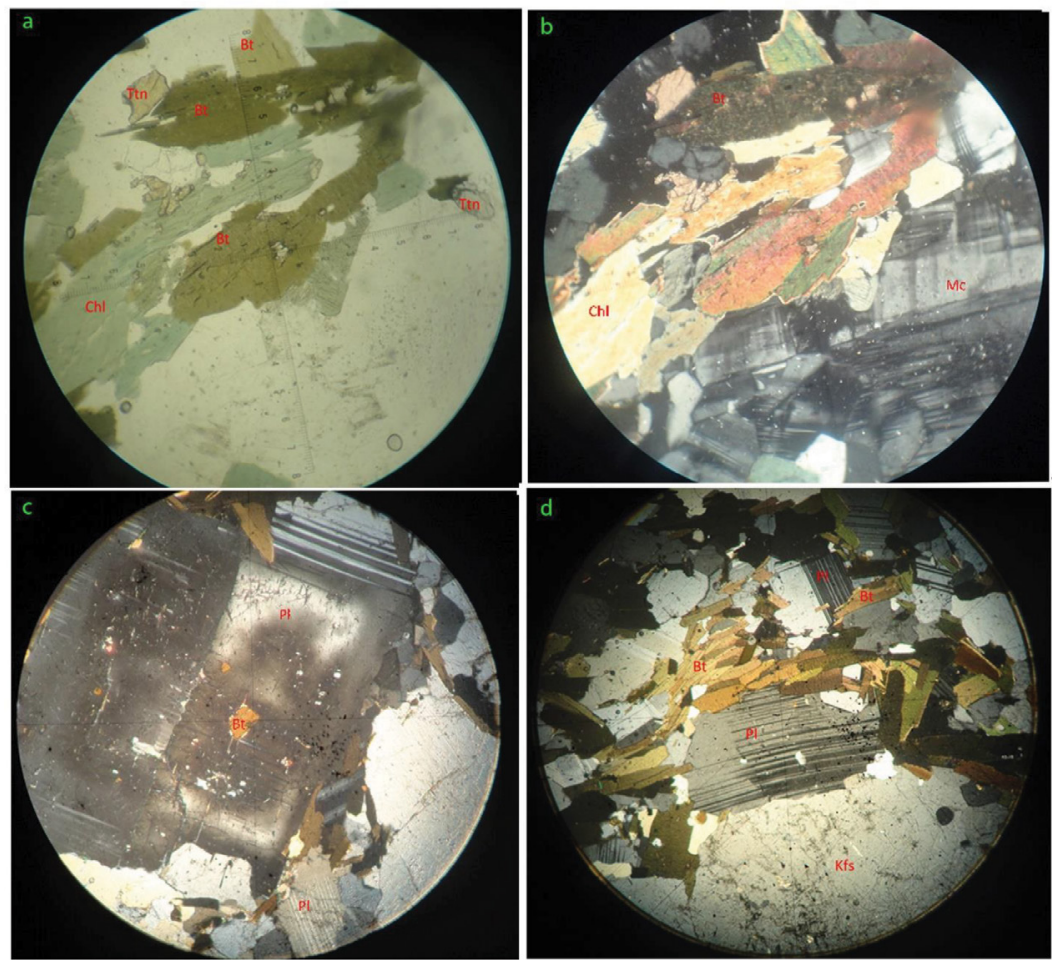

Figure 8: Photomicrographs showing: (a) close association between biotite (Bt) and chlorite (Chl), as well as titanite (Ttn) (PPL). (b) Microcline (Mc) in close relationship with altered biotite (XPL). (c) Compositional zoning of plagioclase, there are biotite (Bt) inclusion in the plagioclase feldspar (PI) (XPL). (d) Plagioclase with deformed twin lamellae and preferred orientation of the biotite (Bt) (XPL).

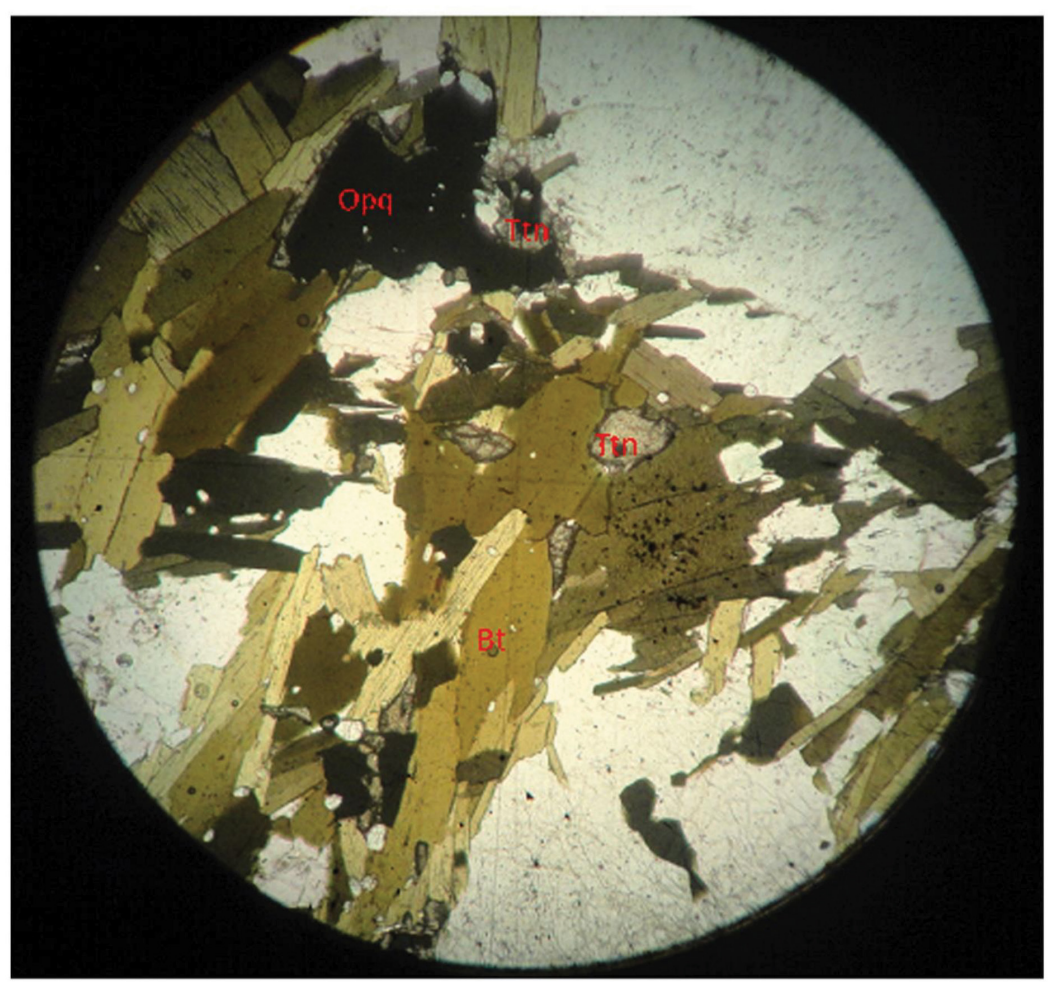

Figure 9: Photomicrograph showing a close relationship between biotite (Bt) and titanite (Ttn). Take a note of reaction rim of titanite (Ttn) round the opaque (Opq) (PPL). 


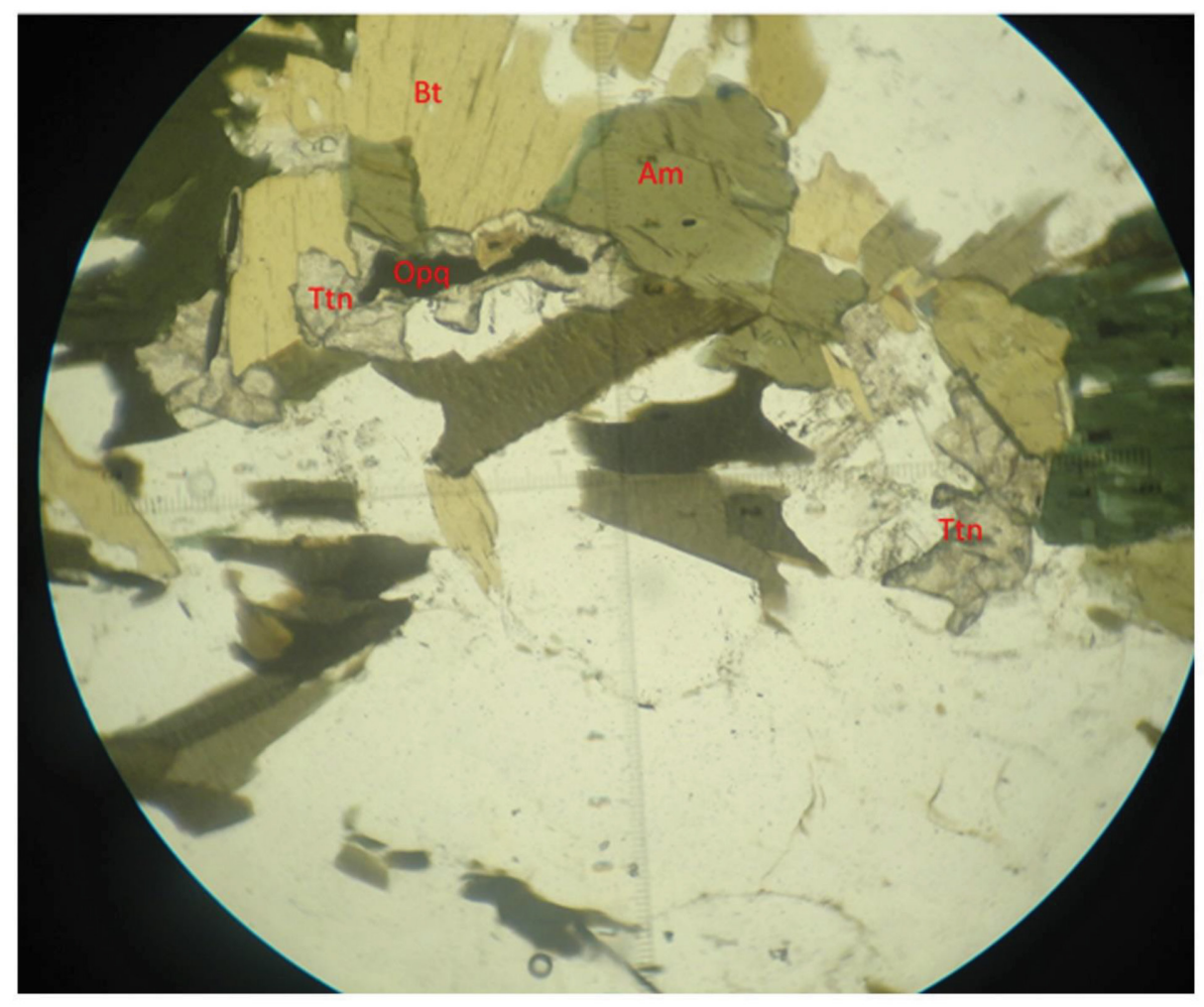

Figure 10: Photomicrograph showing reaction rim of titanite (Ttn) on opaque (Opq) (PPL).

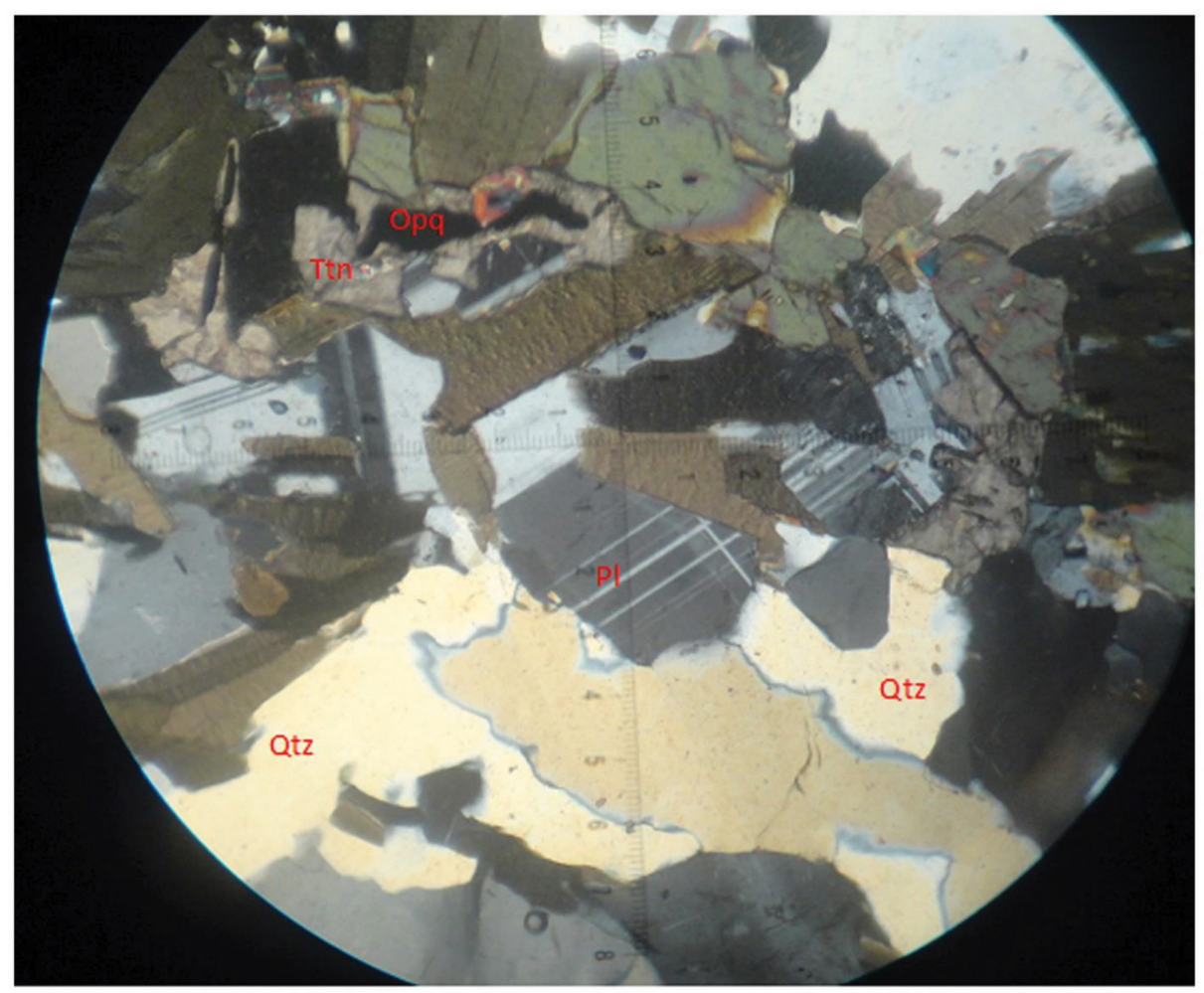

Figure 11: Photomicrograph showing reaction rim of titanite (Ttn) on opaque (Opq) (XPL). 
to opaque mineral, a common phenomenon in granitoids indicating a late fluid activity [22]. Results from experiments suggest that titanite forms as an early phase during crystallisation of magma $[23,24]$. Secondary titanite observed is anhedral and occurs as reaction rim round opaque minerals (Figures 9-11), and this reaction can be supported by the equation given below:

Plagioclase 1 (Ca-rich) + Ilmenite $=>$

Titanite + Plagioclase 2 (Na-rich)

The titanite grains observed show no visible form of zoning. The secondary titanite has been found to be associated with sericitisation of plagioclase and chloritization of biotite as observed in the tonalite [25]. These set of reactions represent retrogressive events probably prompted by moderate heating and fluid activity $[22,26]$ and can be represented by an equation such as:

Plagioclase 1 (Ca-rich) + Biotite $($ Ti-rich $)=>$ Titanite + Chlorite + Plagioclase 2 (Na-rich)

This type of alteration reaction liberates titanium that is locked within biotite [19]. In this regard, titanite can be said to be replacing early biotite and coeval with the chlorite formation (Figure 8a). The opaque mineral is likely to be ilmenite, because ilmenite is an opaque mineral with titanium in its structure. The accessory mineral assemblages such as allanite and titanite have been found to be sensitive to parameters such as temperature, oxygen fugacity, melt composition, as well as the dissolution history of evolving magma $[27,28]$. The apatite which occur as inclusions in biotite can be said to have formed very early during the magmatic process because of the euhedral nature of crystals and occurrence as inclusions in biotite (Figure 6a) and, thus, can be regarded as primary igneous mineral. Plagioclase crystals observed have some of the following features: Carlsbad/albite twinning sericitisation, compositional zoning and deformed twin lamellae (Figures $8 \mathrm{c}$ and $8 \mathrm{~d}$ ). The sericitisation can be supported by the reaction involving plagioclase, biotite, opaque (ilmenite), muscovite, titanite and quartz [22]. Zoned plagioclase could have resulted from rapidly cooled magma leading to disequilibrium growth occurring during large undercooling. Compositional zoning in crystals is a tool in determining the magmatic history of plutonic rocks $[29,30]$. The foliation observed on the outcrop and the deformation of the twin lamellae in the plagioclase is an indication that the rock has been subjected to tectonic activity. Twin lamellae of plagioclase with bent surfaces are common, an indication of syn-magmatic or post-magmatic crystallisation feature.

\section{Conclusion}

The allanite observed is found to have formed early as a result of primary crystallisation and has undergone metamictisation. Both primary and secondary titanite were observed, and the secondary titanite formed at the expense of titanite. The zoned plagioclase is an evidence that there was rapid cooling of magma close to the Earth's surface. Tonalite under study has been subjected to tectonic activities with evidence recorded on the plagioclase and the foliated nature of the rock.

\section{References}

[1] Hubbard, F.H. (1975): Precambrian crustal development in western Nigeria: indications from the Iwo region. Geological Society of America Bulletin, 86(4), pp. 548-554.

[2] Rahaman, M. A. (1976): Review of the basement geology of Southwestern Nigeria. In: Geology of $\mathrm{Ni}$ geria, C.A. Kogbe (ed.). Elizabethan Publishing Co.: Lagos, pp. 41-58.

[3] Poitrasson, F. (2002): In situ investigations of allanite hydrothermal alteration: examples from calc-alkaline and anorogenic granites of Corsica (southeast France). Contributions to Mineralogy and Petrology, 142(4), pp. 485-500.

[4] Gieré, R., Sorensen, S.S. (2004): Allanite and other REE-rich epidote-group minerals. Reviews in Mineralogy and Geochemistry, 56(1), pp. 431-493.

[5] Gromet, L.P., Silver, L.T. (1983): Rare earth element distributions among minerals in a granodiorite and their petrogenetic implications. Geochimica et Cosmochimica Acta, 47(5), pp. 925-939. 
[6] Dawes, R.L., Evans, B.W. (1991): Mineralogy and geothermobarometry of magmatic epidote-bearing dikes, Front Range, Colorado. Geological Society of America Bulletin, 103, pp. 1017-1031.

[7] Catlos, E.J., Sorensen, S.S., Harrison, T.M. (2000): Th$\mathrm{Pb}$ ion-microprobe dating of allanite. American Mineralogist, 85, pp. 633-648.

[8] Jiang, N. (2006): Hydrothermal alteration of chevkinite-(Ce) in the Shuiquangou syenitic intrusion, northern China. Chemical Geology, 227(1-2), pp. 100-112.

[9] Chen, W.T., Zhou, M.F. (2014): Ages and compositions of primary and secondary allanite from the Lala Fe-Cu deposit, SW China: implications for multiple episodes of hydrothermal events. Contributions to Mineralogy and Petrology, 168(2), p. 1043.

[10] Vlach, S.R., Gualda, G.A. (2007): Allanite and chevkinite in A-type granites and syenites of the Graciosa Province, southern Brazil. Lithos, 97(1-2), pp. 98-121.

[11] Mitropoulos, P. (1987): Primary allanite in andesitic rocks from the Poros Volcano, Greece. Mineralogical Magazine, 51(362), pp. 601-604.

[12] Berger, A., Rosenberg, C., Schaltegger, U. (2009): Stability and isotopic dating of monazite and allanite in partially molten rocks: examples from the Central Alps. Swiss Journal of Geosciences, 102(1), pp. 15-29.

[13] Barth, S., Oberli, F., Meier, M. (1989): U-Th-Pb systematics of morphologically characterized zircon and allanite: a high-resolution isotopic study of the Alpine Rensen pluton (northern Italy). Earth Planet Sci Lett, 95, pp. 235-254.

[14] Barth, S., Oberli, F., Meier, M. (1994): Th-Pb versus $\mathrm{U}-\mathrm{Pb}$ isotope systematics in allanite from co-genetic rhyolite and granodiorite: implications for geochronology. Earth Planet Sci Lett, 124, pp. 149-159.

[15] Davis, D.W., Schandl, E.S., Wasteneys, H.A. (1994): $\mathrm{U}-\mathrm{Pb}$ dating of mineral alteration in halos of Superior Province massive sulfide deposits: syngenesis versus metamorphism. Contrib Mineral Petrol, 115, pp. 427-437.

[16] Gregory, C.J., Rubatto, D., Allen, C.M., Williams, I.S., Hermann, J., Ireland, T. (2007): Allanite micro-geochronology: a LA-ICP-MS and SHRIMP U-Th-Pb study. Chemical Geology, 245(3-4), pp. 162-182.

[17] Darling, J.R., Storey, C.D., Engi, M. (2012): Allanite $\mathrm{U}-\mathrm{Th}-\mathrm{Pb}$ geochronology by laser ablation ICPMS. Chemical Geology, 292, pp. 103-115.
[18] McFarlane, C. R. (2016): Allanite UPb geochronology by $193 \mathrm{~nm}$ LA ICP-MS using NIST610 glass for external calibration. Chemical Geology, 438, pp. 91-102.

[19] Rimsaite, J. (1982): Alteration of Radioactive Minerals in Granite and Related Secondary Uranium Mineralizations. In: Ore Genesis. Springer: Berlin, Heidelberg, pp. 269-280.

[20] Janeczek, J., Eby, R.K. (1993): Annealing of radiation damage in allanite and gadolinite. Physics and Chemistry of Minerals, 19(6), pp. 343-356.

[21] Wood, S.A., Ricketts, A. (2000): Allanite-(Ce) from the Eocene Casto granite, Idaho: response to hydrothermal alteration. The Canadian Mineralogist, 38(1), pp. 81-100.

[22] Broska, I., Harlov, D., Tropper, P., Siman, P. (2007): Formation of magmatic titanite and titanite-ilmenite phase relations during granite alteration in the Tribeč Mountains, Western Carpathians, Slovakia. Lithos, 95(1-2), pp. 58-71.

[23] Watson, E.B., Harrison, T.M. (1984): Accessory minerals and the geochemical evolution of crustal magmatic systems: a summary and prospectus of experimental approaches. Phys. Earth Planet. Int., 1984, 35, pp. 19-30.

[24] Xirouchakis, D., Lindsley, D.H. (1998): Equilibria among titanite, hedenbergite, fayalite, quartz, ilmenite, and magnetite: experiments and internally consistent thermodynamic data for titanite. Am. Mineral., 83, pp. 712-749.

[25] Putnis, A. (2002): Mineral replacement reactions: from macroscopic observation to microscopic mechanism. Mineral. Mag. 66, pp. 689-708.

[26] Corfu, F., Stone, D. (1998): The significance of titanite and apatite $\mathrm{U}-\mathrm{Pb}$ ages: constraints for the post-magmatic thermal-hydrothermal evolution of a batholithic complex, Berens River area, northwestern Superior Province, Canada. Geochim. Cosmochim. Acta, 62, pp. 2979-2995.

[27] Paterson, B. A., Stephens, W. E., Herd, D. A. (1989): Zoning in granitoid accessory minerals as revealed by backscattered electron imagery. Mineral. Mag., 53, pp. 55-61.

[28] Wones, D.R. (1989): Significance of the assemblage titanite + magnetite quartz in granitic rocks. Am. Mineral., 74, pp. 744-749.

[29] Loomis, T.P. (1981): An investigation of disequilibrium growth processes of plagioclase in the system anorthite-albite-water by methods of numerical simulation. Contributions to Mineralogy and Petrology, 76(2), pp. 196-205. 
[30] Loomis, T.P., Welber, P.W. (1982): Crystallization processes in the Rocky Hill granodiorite pluton, California: an interpretation based on compositional zoning of plagioclase. Contributions to Mineralogy and Petrology, 81(3), pp. 230-239. 